\title{
TOURISTS PERCEPTION OF "MEPANTIGAN," BALINESE TRADITIONAL MARTIAL ART AS ALTERNATIVE TOURISM ATTRACTION IN GIANYAR, BALI
}

\author{
Komang Trisna Pratiwi Arcana, Trivena Hani, I Made Sudjana. \\ International Bali Tourism Institute. Indonesia \\ trisnapratiwi.arcana@gmail.com
}

\begin{abstract}
The study examined the perception of tourists on "Mepantigan" as alternative tourism in Pondok Mepantigan in Gianyar Bali. The background of this research is the emergence of "Mepantigan" attraction that is developing. Obviously, "Mepantigan" is a unique and first tourist attraction in Gianyar Bali by elevating traditional martial arts and combined with the art of dance and music with the game set in the mud. The purpose of this study is to identify the perception of tourists to "Mepantigan" as alternative tourism in Pondok Mepantigan in Gianyar Bali. In essence research method using the qualitative and quantitative method. Data analysis techniques used descriptive-qualitative, where data obtained from observation, interview, documentation and questionnaire to tourism components such as attraction, accessibility, amenities, available packages, activities, and ancillary services. Sustainable tourism paradigm and can be applied to alternative tourism is tourism activity. The research results showed that Pondok Mepantigan is an attractive tourist attraction because it has a natural tourist attraction, culture and artificial but need to increase the availability of supporting facilities for tourists. In essence, Pondok Mepantigan has met the parameters as alternative tourism but need to improve in empowering communities around Pondok Mepantigan.
\end{abstract}

Keywords: Mepantigan; Alternative Tourism; Tourists Perception; Gianyar - Bali

\section{INTRODUCTION}

Tourism is one of the potential sectors in improving the economy of the country and the economy of the people. According to the United Nations World Tourism Organization (2015) and the World Travel and Tourism Council (2015) in the Tourism Bulletin (2015: 16) described tourism as a key factor in income, job creation, business development and infrastructure, the largest and fastest growing economic sector in both the economy and the growth of tourist travels that show positive growth. 
In Arcana (2004), Buhalis argued that tourist destinations consist of several core components as follows:

1. Attractions, that include nature, artificial, artificial buildings, and special events.

2. Accessibility, which includes transportation system.

3. Amenities, consist of accommodation, restaurant, and other tourist services.

4. Available package, that is tour packages that have been prepared by the tour operator or travel agency.

5. Activities, i.e. all activities that can be done by tourists when they are in the destination.

6. Ancillary services refer to banks, telecommunications, postal services, money changers, hospitals, and others.

Bali is an area that has increased the visiting number of domestic tourists and abroad each year. Central Bureau of Statistics described the number of domestic tourists visiting Bali in 2015 of 7,147,100 tourists while in 2016, domestic tourists visiting Bali of 8,643,680 tourists. In 2015 the number of foreign tourists visiting Bali amounted to $4,001,835$ tourists while in 2016 foreign tourists to Bali amounted to $4,927,937$. The increase of visiting number of domestic and abroad is because Bali has a beauty in the form of natural, cultural and artificial attractions or special interests.

Development of Gianyar Regency as a leading sector is the realisation of cultural tourism quality, competitive, sustainable and prosperous. In achieving the realization of Gianyar Regency as a leading sector, it is necessary to realize tourism that is oriented towards the preservation of culture, nature or environment, and oriented towards community empowerment. The tourism breakthrough in Gianyar Regency is alternative tourism.

Alternative tourism is a tourism activity that does not damage the environment to the community, ecological and avoid the negative impact of mass tourism or large-scale tourism that can threaten the culture. Alternative tourism can serve as one of the attractions and attractions of interest. According to Middleton in Valene (2001), alternative tourism is a form of tourism products that consider even demand a more environmentally friendly and non-destructive culture. Suwantoro (2004) added that alternative tourism is a form of tourism that arises as a reaction to the negative impacts of conventional tourism development and development. Alternative tourism is also a different form of tourism (which is an alternative) of conventional tourism to support environmental sustainability.

Pondok Mepantigan presents a mepantigan attraction, a traditional Balinese martial art form involving physical techniques similar to those found in martial arts traditions around the world. The martial arts are combined with drama, Balinese dance and gamelan music, as well as martial arts from other countries to create an entirely new cultural phenomenon called mepantigan, which means slamming each other. Mepantigan is unique because it is the only one in Bali. Mepantigan is done in mud ponds but tourists still follow the attractions that exist despite playing with mud. Based on this matter then Pondok Mepantigan can be studied further about the perception of tourists to mepantigan as alternative tourism in Pondok Mepantigan in Gianyar Bali. The research aimed to find out how the perceptions of 
tourists are to mepantigan as alternative tourism in Pondok Mepantigan in Gianyar Bali.

This research is a chance for applying the theories obtained during being in college with the reality that exists in the field. For Sekolah Tinggi Pariwisata Bali Internasional, this research can be used as a reference in the library in the field of tourism science and tourism science learning development. For Pondok Mepantigan as a reference and consideration of decision making especially in matters relating to the perception of tourists to mepantigan as alternative tourism in Pondok Mepantigan in Gianyar Bali.

\section{METHODOLOGY}

The research was conducted at Pondok Mepantigan located in Batubulan village, Sukawati District, Gianyar Regency, Bali. It is exactly located on Jalan Pasekan Pondok Batu Alam No.30 Banjar Tubuh. This research was conducted in JanuaryJuly 2017. Data collection was done by interview, observation, questionnaire and documentation.

According to Pantiyasa (2013) incidental sampling is a sample determination technique based on coincidence that anyone who happens to meet with research can be used as a sample, when viewed as a coincidence is suitable as a respondent. The number of samples obtained in Pondok Mepantigan is 40 tourists consisting of foreign tourists and local tourists. Data analysis techniques used are qualitative descriptive, which is intended to investigate the conditions, conditions or other things already mentioned and the results are described in the form report (Arikunto, 2010).

\section{RESULT AND DISCUSSION}

Based on table 4.1 it can be seen that the number of respondents in Pondok Mepantigan based on gender amounted to 40 respondents with details of 20 men and 20 women. Percentage of male respondents by 50 percent and female respondents by 50 percent. Characteristics of respondents by age are used to know vulnerable aged playing mepantigan in Pondok Mepantigan. Based on the number of respondents in Pondok Mepantigan by age known number of respondents aged under 20 years is 10 people with a percentage of 25 per cent. Age of respondents 21-30 years old are 19 people with a percentage of 47.5 per cent. Age of respondents 31-40 years old are 8 people with a percentage of 20 percent. Age of respondents over 40 years are 3 people with a percentage of 7.5 per cent. The number of respondents in Pondok Mepantigan by age is 21-30 years old and the smallest is aged over 40 years. It can be reviewed based on the respondent's occupation to know the information of the respondent's data and clarify the respondent's data; it is known that the number of respondent's occupation is mostly in the students with the number of 15 people and the percentage is 37.5 per cent. The occupation of the smallest respondents is 2 people in housewives with a total percentage of 5 percent. The occupation of respondents as government employee are 5 people with a percentage of 12.5 percent. Occupations that do not want to be mentioned by the respondent with personal reasons are 11 people with a percentage of 17.5 percent. If it is reviewed based on the respondents' income to know the suitability and ability 
of the respondents to follow the activities in Pondok Mepantigan, it is known that the income of 1 million to 2.5 million rupiahs is 19 people with the percentage of 47.5 per cent. Income of 2.5 million -5 million rupiahs for 6 people with a percentage of 15 percent. The income of 5 million-7 million rupiahs for 2 people with a percentage of 5 percent. Income above 7 million rupiah as many as 13 people with a percentage of 32.5 percent.

Tourists who come to Pondok Mepantigan will pass a bamboo bridge that will melt the atmosphere because deliberately made wobbling like a bridge is outdated. When crossing the bamboo bridge, tourists will be greeted with mask dance and given typical clothes of Pondok Mepantigan. Tourists get ready before starting the game and served traditional Balinese snack as well as welcome drink in bamboo glass. Attractions at Pondok Mepantigan give a perception to tourists. It can be seen from 40 respondents 14 respondents agreed with the percentage of 35 per cent while 26 respondents stated strongly agree to bamboo bridge because it is unique and interesting for respondents with a percentage of 65 percent.

Table 4.1 The Characteristics of Respondents in Pondok Mepantigan

\begin{tabular}{|c|c|c|c|c|}
\hline Num & & Description & Amount & Percentage \\
\hline \multirow{2}{*}{1} & \multirow{2}{*}{ Gender } & Male & 20 people & $50 \%$ \\
\hline & & Female & 20 people & $50 \%$ \\
\hline & \multicolumn{2}{|l|}{ Total } & 40 people & $100 \%$ \\
\hline \multirow{5}{*}{2} & \multirow{4}{*}{ Age } & Less than 20 years old & 10 people & $25 \%$ \\
\hline & & $21-30$ years old & 19 people & $47.5 \%$ \\
\hline & & 31 - 40 years old & 8 people & $20 \%$ \\
\hline & & More than 41 years old & 3 people & $7.5 \%$ \\
\hline & \multicolumn{2}{|l|}{ Total } & 40 people & $100 \%$ \\
\hline \multirow{6}{*}{3} & \multirow{5}{*}{ Occupation } & Student & 15 people & $37.5 \%$ \\
\hline & & Civil Worker & 5 people & $12.5 \%$ \\
\hline & & Housewife & 2 people & $5 \%$ \\
\hline & & Enterpreneur & 7 people & $17.5 \%$ \\
\hline & & Others & 11 people & $27.5 \%$ \\
\hline & \multicolumn{2}{|l|}{ Total } & 40 people & $100 \%$ \\
\hline \multirow{10}{*}{4} & \multirow{9}{*}{ Recent education } & Elementary & 8 people & $20 \%$ \\
\hline & & Junior High School & - & - \\
\hline & & Senior High School & 11 people & $27.5 \%$ \\
\hline & & Collage & 2 people & $5 \%$ \\
\hline & & Vocational Degree & 1 people & $2.5 \%$ \\
\hline & & Associates Degree & - & - \\
\hline & & Bachelor's Degree & 14 people & $35 \%$ \\
\hline & & Master's Degree & 4 people & $10 \%$ \\
\hline & & Doctorate Degree & - & - \\
\hline & \multicolumn{2}{|l|}{ Total } & 40 people & $100 \%$ \\
\hline 5 & Nationality & Indonesian & 22 people & $55 \%$ \\
\hline
\end{tabular}




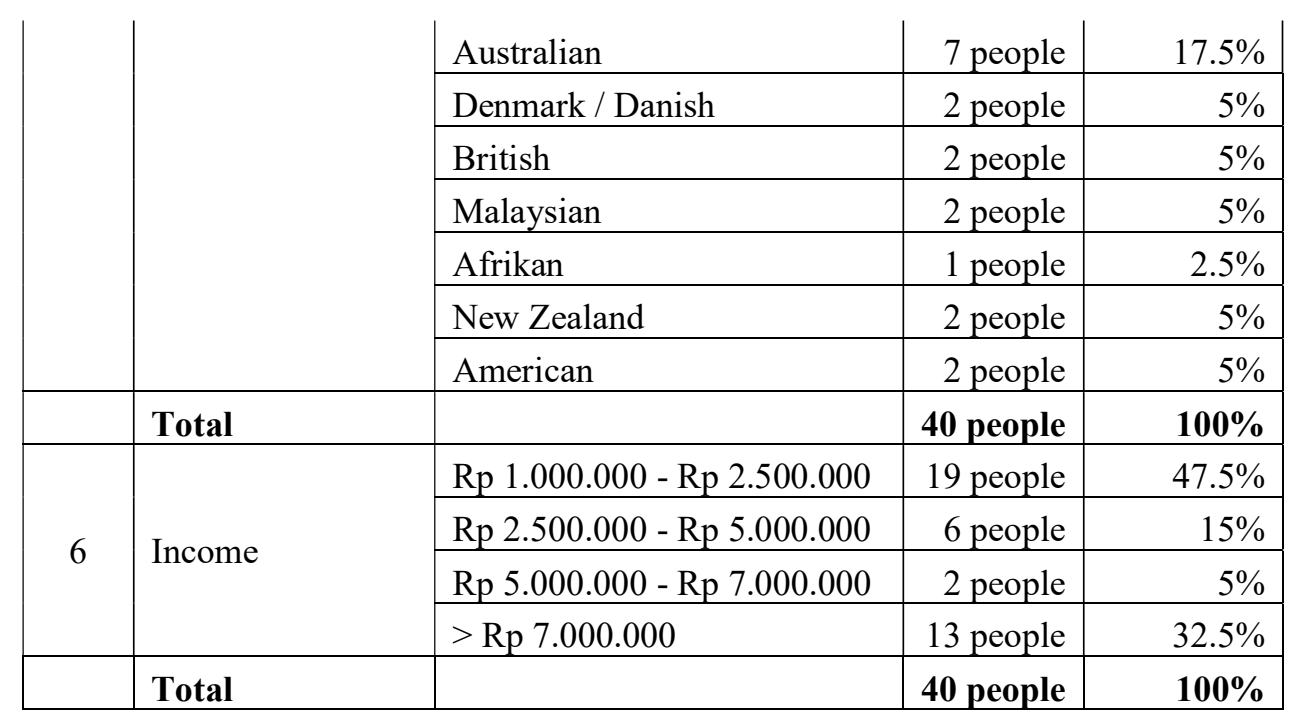

Source: Research Results, 2017

Respondents who are happy with the mask dance reception stated strongly agree as many as 26 respondents with a percentage of 65 per cent, around 13 respondents agree with a percentage of 32.5 per cent and 1 respondent is hesitant with a percentage of 2.5 per cent because less interesting. Respondents who liked to wear typical mepantigan clothes stated strongly agree as many as 25 respondents with a percentage of 62.5 per cent, 10 respondents agree with a percentage of 25 per cent, 4 respondents are hesitant with a percentage of 10 per cent and 1 disagree with a percentage of 2.5 per cent due to feeling uncomfortable with the clothes that exist. Respondents who are happy and interested to try a typical snack stated strongly agree as many as 27 respondents with a percentage of 67.5 per cent, 8 respondents agree with a percentage of 20 per cent and 5 respondents are hesitant with a percentage of 2.5 per cent. Respondents who are happy and feel welcome welcome drink in bamboo is very unique states strongly agree as many as 29 respondents with a percentage of 72.5 per cent, 9 respondents agree with a percentage of 22.5 per cent and 2 respondents are hesitant with a percentage of 5 per cent.

Table 4.2 Tourist Perceptions of Attractions in Pondok Mepantigan

\begin{tabular}{|c|l|l|c|c|}
\hline No & \multicolumn{1}{|c|}{ Statement } & \multicolumn{1}{|c|}{ Perception } & Amount & Percentage \\
\hline \multirow{3}{*}{1.} & \multirow{2}{*}{$\begin{array}{l}\text { Bamboo bridge is unique } \\
\text { and interesting for me }\end{array}$} & Strongly Agree (5) & 26 People & $65 \%$ \\
\cline { 3 - 5 } & & Agree (4) & 14 People & $35 \%$ \\
\cline { 3 - 5 } & $\begin{array}{l}\text { Neither Agree nor } \\
\text { Disagree (3) }\end{array}$ & - & - \\
\cline { 3 - 5 } & Disagree & - & - \\
\cline { 3 - 5 } & Ttrongly Disagree & - & - \\
\hline \multicolumn{2}{|c|}{ Total } \\
\hline \multirow{2}{*}{2.} & $\begin{array}{l}\text { I feel pleased with the } \\
\text { welcoming of topeng dance }\end{array}$ & Strongly Agree (5) & 26 People & $65 \%$ \\
\cline { 3 - 5 } & Agree (4) & 13 People & $32,5 \%$ \\
\hline
\end{tabular}




\begin{tabular}{|c|c|c|c|c|}
\hline & & $\begin{array}{l}\text { Neither Agree nor } \\
\text { Disagree (3) }\end{array}$ & 1 People & $2,5 \%$ \\
\hline & & Disagree & - & - \\
\hline & & Strongly Disagree & - & - \\
\hline \multicolumn{3}{|c|}{ Total } & 40 People & $100 \%$ \\
\hline \multirow[t]{5}{*}{3.} & \multirow{5}{*}{$\begin{array}{l}\text { I am pleased with } \\
\text { mepantigan typical clothes }\end{array}$} & Strongly Agree (5) & 25 People & $62,5 \%$ \\
\hline & & Agree (4) & 10 People & $25 \%$ \\
\hline & & $\begin{array}{l}\text { Neither Agree nor } \\
\text { Disagree (3) }\end{array}$ & 4 People & $10 \%$ \\
\hline & & Disagree & 1 People & $2,5 \%$ \\
\hline & & Strongly Disagree & - & - \\
\hline \multicolumn{3}{|c|}{ Total } & 40 People & $100 \%$ \\
\hline \multirow[t]{5}{*}{4.} & \multirow{5}{*}{$\begin{array}{l}\text { I am glad and interested to } \\
\text { taste Bali traditional snack }\end{array}$} & Strongly Agree (5) & 27 People & $67,5 \%$ \\
\hline & & Agree (4) & 8 People & $20 \%$ \\
\hline & & $\begin{array}{l}\text { Neither Agree nor } \\
\text { Disagree (3) }\end{array}$ & 5 People & $12,5 \%$ \\
\hline & & Disagree & - & - \\
\hline & & Strongly Disagree & - & - \\
\hline \multicolumn{3}{|c|}{ Total } & 40 People & $100 \%$ \\
\hline \multirow[t]{5}{*}{5.} & \multirow{5}{*}{$\begin{array}{l}\text { I am pleased and feel the } \\
\text { welcoming drink in bamboo } \\
\text { is unique }\end{array}$} & Strongly Agree (5) & 29 People & $72,5 \%$ \\
\hline & & Agree (4) & 9 People & $22,5 \%$ \\
\hline & & \begin{tabular}{|l|} 
Neither Agree nor \\
Disagree (3) \\
\end{tabular} & 2 People & $5 \%$ \\
\hline & & Disagree & - & - \\
\hline & & Strongly Disagree & - & - \\
\hline \multicolumn{3}{|c|}{ Total } & 40 People & $100 \%$ \\
\hline
\end{tabular}

Source: Research Results, 2017

Table 4.3 Tourist Perceptions of Accessibility in Pondok Mepantigan

\begin{tabular}{|c|c|c|c|c|}
\hline No & Statement & Perception & Amount & $\begin{array}{c}\text { Percentag } \\
\mathrm{e}\end{array}$ \\
\hline \multirow[t]{5}{*}{1.} & \multirow{5}{*}{$\begin{array}{l}\text { I feel the route, or the way } \\
\text { passed to the Pondok } \\
\text { Mepantigan was good }\end{array}$} & Strongly Agree (5) & 13 People & $32,5 \%$ \\
\hline & & Agree (4) & 14 People & $35 \%$ \\
\hline & & $\begin{array}{l}\text { Neither Agree nor } \\
\text { Disagree (3) }\end{array}$ & 11 People & $27,5 \%$ \\
\hline & & Disagree & 2 People & $5 \%$ \\
\hline & & Strongly Disagree & - & - \\
\hline \multicolumn{3}{|c|}{ Total } & 40 People & $100 \%$ \\
\hline \multirow[t]{5}{*}{2.} & \multirow{5}{*}{$\begin{array}{l}\text { According to me the } \\
\text { transportation used to the } \\
\text { Pondok Mepantigan was } \\
\text { good }\end{array}$} & Strongly Agree (5) & 13 People & $32,5 \%$ \\
\hline & & Agree (4) & 15 People & $37,5 \%$ \\
\hline & & $\begin{array}{l}\text { Neither Agree nor } \\
\text { Disagree (3) }\end{array}$ & 10 People & $25 \%$ \\
\hline & & Disagree & 2 People & $5 \%$ \\
\hline & & Strongly Disagree & - & - \\
\hline \multicolumn{3}{|c|}{ Total } & 40 People & $100 \%$ \\
\hline 3. & & Strongly Agree (5) & 13 People & $32,5 \%$ \\
\hline
\end{tabular}




\begin{tabular}{|c|c|c|c|c|}
\hline & \multirow{4}{*}{$\begin{array}{l}\text { I feel the distance and time to } \\
\text { Pondok Mepantigan was } \\
\text { good }\end{array}$} & Agree (4) & 16 People & $40 \%$ \\
\hline & & $\begin{array}{l}\text { Neither Agree nor } \\
\text { Disagree (3) }\end{array}$ & 9 People & $22,5 \%$ \\
\hline & & Disagree & 2 People & $5 \%$ \\
\hline & & Strongly Disagree & - & - \\
\hline \multicolumn{3}{|c|}{ Total } & 40 People & $100 \%$ \\
\hline \multirow[t]{5}{*}{4.} & \multirow{5}{*}{$\begin{array}{l}\text { I feel the distance from } \\
\text { Pondok Mepantigan to the } \\
\text { other tourist destinations is } \\
\text { very easy and adequate }\end{array}$} & Strongly Agree (5) & 12 People & $30 \%$ \\
\hline & & Agree (4) & 14 People & $35 \%$ \\
\hline & & $\begin{array}{l}\text { Neither Agree nor } \\
\text { Disagree (3) }\end{array}$ & 12 People & $30 \%$ \\
\hline & & Disagree & 2 People & $5 \%$ \\
\hline & & Strongly Disagree & - & - \\
\hline \multicolumn{3}{|c|}{ Total } & 40 People & $100 \%$ \\
\hline
\end{tabular}

Source: Research Results, 2017

Based on table 4.3 above, Pondok Mepantigan had both stated strongly agree as many as 13 respondents with percentage of 32.5 percent, agree 14 respondents with percentage of 35 percent, neither agree nor disagree 11 respondents with percentage of 27.5 percent and disagree 2 respondents with percentage by 5 percent due to the location of Pondok Mepantigan in remote areas. Respondents who stated strongly agree on the transportation used to Pondok Mepantigan had good as many as 13 respondents with percentage of 32.5 per cent, agreed 15 respondents with percentage of 37.5 per cent, neither agree nor disagree 10 respondents with percentage of 25 percent and disagree 2 respondents with Percentage of 5 percent due to less flexible transportation. Respondents who stated strongly agree on the distance and time to Pondok Mepantigan had good as many as 13 respondents with a percentage of 32.5 per cent, agreed 16 respondents with a percentage of 40 per cent, neither agree nor disagree 9 respondents with the percentage of 22.5 percent and disagree 2 respondents with percentage of 5 percent. Respondents who stated strongly agree on the distance from Pondok Mepantigan to other tourist attractions is very easy and adequate as many as 12 respondents with percentage of 30 per cent, agreed 14 respondents with percentage of 35 per cent, neither agree nor disagree 12 respondents with a percentage of 30 percent and disagree 2 respondents with percentage of 5 percent due to congestion and a considerable distance.

Table 4.4 Tourist Perception of Accommodation in Pondok Mepantigan

\begin{tabular}{|c|c|c|c|c|}
\hline $\begin{array}{l}\mathrm{N} \\
\mathrm{O}\end{array}$ & Statement & Persepsi / Penilaian & Amount & $\begin{array}{c}\text { Percentag } \\
\mathrm{e}\end{array}$ \\
\hline \multirow[t]{5}{*}{1.} & \multirow{5}{*}{$\begin{array}{l}\text { I am satisfied with food } \\
\text { and beverage supply at } \\
\text { Pondok Mepantigan }\end{array}$} & Strongly Agree (5) & 27 People & $67,5 \%$ \\
\hline & & Agree (4) & 10 People & $25 \%$ \\
\hline & & $\begin{array}{l}\text { Neither Agree nor } \\
\text { Disagree (3) }\end{array}$ & 3 People & $7,5 \%$ \\
\hline & & Disagree & - & - \\
\hline & & Strongly Disagree & - & - \\
\hline \multicolumn{3}{|c|}{ Total } & 40 People & $100 \%$ \\
\hline 2. & & Strongly Agree (5) & 21 People & $52,5 \%$ \\
\hline
\end{tabular}




\begin{tabular}{|c|c|c|c|c|}
\hline & \multirow{4}{*}{$\begin{array}{l}\text { I feel the lodging provided } \\
\text { is adequate }\end{array}$} & Agree (4) & 10 People & $25 \%$ \\
\hline & & $\begin{array}{l}\text { Neither Agree nor } \\
\text { Disagree (3) }\end{array}$ & 8 People & $20 \%$ \\
\hline & & Disagree & 1 People & $2,5 \%$ \\
\hline & & Strongly Disagree & - & - \\
\hline \multicolumn{3}{|c|}{ Total } & 40 People & $100 \%$ \\
\hline \multirow[t]{5}{*}{3.} & \multirow{5}{*}{$\begin{array}{l}\text { There is information centre } \\
\text { which makes me easy }\end{array}$} & Strongly Agree (5) & 20 People & $50 \%$ \\
\hline & & Agree (4) & 8 People & $20 \%$ \\
\hline & & $\begin{array}{l}\text { Neither Agree nor } \\
\text { Disagree (3) }\end{array}$ & 10 People & $25 \%$ \\
\hline & & Disagree & 2 People & $5 \%$ \\
\hline & & Strongly Disagree & - & - \\
\hline \multicolumn{3}{|c|}{ Total } & 40 People & $100 \%$ \\
\hline \multirow[t]{5}{*}{4.} & \multirow{5}{*}{$\begin{array}{l}\text { The availability of internet } \\
\text { was good and adequate for } \\
\text { me }\end{array}$} & Strongly Agree (5) & 18 People & $45 \%$ \\
\hline & & Agree (4) & 11 People & $27,5 \%$ \\
\hline & & $\begin{array}{l}\text { Neither Agree nor } \\
\text { Disagree (3) }\end{array}$ & 10 People & $25 \%$ \\
\hline & & Disagree & 1 People & $2,5 \%$ \\
\hline & & Strongly Disagree & - & - \\
\hline \multicolumn{3}{|c|}{ Total } & 40 People & $100 \%$ \\
\hline \multirow[t]{5}{*}{5.} & \multirow{5}{*}{$\begin{array}{l}\text { I am pleased with the } \\
\text { presence of souvenir shop } \\
\text { at Pondok Mepantigan }\end{array}$} & Strongly Agree (5) & 15 People & $37,5 \%$ \\
\hline & & Agree (4) & 13 People & $32,5 \%$ \\
\hline & & $\begin{array}{l}\text { Neither Agree nor } \\
\text { Disagree (3) }\end{array}$ & 10 People & $25 \%$ \\
\hline & & Disagree & 2 People & $5 \%$ \\
\hline & & Strongly Disagree & - & - \\
\hline \multicolumn{3}{|c|}{ Total } & 40 People & $100 \%$ \\
\hline
\end{tabular}

Source: Research Results, 2017

Based on Table 4.4, the respondents are satisfied with the provision of food and beverages at Pondok Mepantigan stated strongly agree as many as 27 respondents with percentage of 67.5 per cent, 10 respondents agree with percentage of 25 per cent and 3 respondents are hesitant with percentage of 7.5 per cent due to differences in taste and appearance of food served. Respondents who stated strongly agree on the inn or homestay provided adequate as many as 21 respondents with a percentage of 52.5 per cent, 10 agree on respondents with a percentage of 25 per cent, 8 respondents are hesitant with a percentage of 20 per cent due to being in the open and 1 respondent disagree with a percentage of 2.5 per cent due to according to respondents inadequate. The existence of the information centre gives convenience for the respondents stated strongly agree 20 respondents with percentage of 50 per cent, 8 respondents agree with percentage of 20 per cent, 10 respondents hesitate with percentage of 25 per cent due to lack of direction and 2 respondents disagree with percentage of 5 per cent because the directions are difficult to reach. Respondents who stated strongly agree on the availability of toilets is good and adequate as many as 18 respondents with a percentage of 45 per cent, 11 respondents agree with a percentage of 27.5 per cent, 10 respondents are hesitant with a percentage of 25 per cent and 1 respondent disagree with a 
percentage of 2.5 per cent due to the condition of the toilet that according to respondents is inadequate. Respondents who stated strongly agree to be happy with souvenir or souvenir shop in Pondok Mepantigan as many as 15 respondents with percentage of 37.5 per cent, 13 respondents agree with percentage of 32.5 per cent, tentative 10 respondents with percentage of 25 percent and 2 respondents disagreed with a percentage of 5 percent due to lack of complete souvenirs that exist.

Table 4.5 Tourists Perception of Available Packages in Pondok Mepantigan

\begin{tabular}{|c|c|c|c|c|}
\hline $\begin{array}{l}\mathrm{N} \\
\mathrm{O}\end{array}$ & Statement & Persepsi / Penilaian & Amount & $\begin{array}{c}\text { Percentag } \\
\mathrm{e}\end{array}$ \\
\hline \multirow[t]{5}{*}{1.} & \multirow{5}{*}{$\begin{array}{l}\text { I feel the package price at } \\
\text { Pondok Mepantigan is } \\
\text { affordable }\end{array}$} & Strongly Agree (5) & 14 People & $35 \%$ \\
\hline & & Agree (4) & 17 People & $42,5 \%$ \\
\hline & & $\begin{array}{l}\text { Neither Agree nor } \\
\text { Disagree (3) }\end{array}$ & 8 People & $20 \%$ \\
\hline & & Disagree & 1 People & $2,5 \%$ \\
\hline & & Strongly Disagree & - & - \\
\hline \multicolumn{3}{|c|}{ Total } & 40 People & $100 \%$ \\
\hline \multirow[t]{5}{*}{2.} & \multirow{5}{*}{$\begin{array}{l}\text { I feel pleased with the } \\
\text { package provided at } \\
\text { Pondok Mepantigan }\end{array}$} & Strongly Agree (5) & 16 People & $40 \%$ \\
\hline & & Agree (4) & 18 People & $45 \%$ \\
\hline & & $\begin{array}{l}\text { Neither Agree nor } \\
\text { Disagree (3) }\end{array}$ & 6 People & $15 \%$ \\
\hline & & Disagree & - & - \\
\hline & & Strongly Disagree & - & - \\
\hline \multicolumn{3}{|c|}{ Total } & 40 People & $100 \%$ \\
\hline
\end{tabular}

Source: Research Results, 2017

Based on table 4.5, the respondents who felt the price of the package at Pondok Mepantigan is affordable stated strongly agree as many as 14 respondents with percentage of 35 percent, agree 17 respondents with percentage of 42.5 percent, neither agree nor disagree 8 respondents with percentage of 20 percent and disagree 1 respondents with percentage of 2.5 percent because respondents feel the price of the package provided is not affordable. Respondents who stated strongly agree on the feeling of pleasure with the package provided at Pondok Mepantigan as many as 16 respondents with the percentage of 40 per cent, agree 18 respondents with the percentage of 45 per cent and neither agree nor disagree 6 respondents with percentage of 15 per cent because the package provided is less diverse.

Respondents who are happy with mask painting activity stated strongly agree as many as 25 respondents with the percentage of 62.5 per cent, agree 12 respondents with the percentage of 30 per cent and neither agree nor disagree 3 respondents with the percentage of 7.5 per cent due to respondents according to the activity is less interesting. Respondents who stated strongly agree on the feeling of fun doing mepantigan exercises before playing in the mud as much as 27 respondents with Percentage of 67.5 per cent, agree 12 respondents with the percentage of 30 per cent, and neither agree nor disagree 1 respondent with the percentage of 2.5 per cent. Respondents who stated strongly agree on the feeling of fun doing mepantigan game in the mud as much as 30 respondents with a percentage 
of 75 per cent, agree 9 respondents with the percentage of 22.5 per cent, and neither agree nor disagree 1 respondent with percentage of 2.5 per cent due to uncomfortable respondents with mud. Respondents who were attracted by the unique words during the play mepantigan and make respondents enthusiasm stated strongly as much as 28 respondents with percentage of 70 per cent, agree 11 respondents with percentage of 27.5 per cent and neither agree nor disagree 1 respondent with percentage of 2.5 per cent. Respondents who are happy with washing clothes in the river stated strongly agree to agree as many as 22 respondents with Percentage of 55 per cent, agree 15 respondents with percentage of 37.5 per cent, neither agree nor disagree 2 respondents with percentage of 5 per cent and disagree 1 respondent with percentage by 2.5 per cent. Respondents who are happy and feel challenged by fireballs stated strongly agree as many as 25 respondents with percentage of 62.5 per cent, agree 12 respondents with percentage of 30 per cent and neither agree nor disagree 3 respondents with percentage of 7.5 per cent due to the respondents were afraid of game fireballs.

Table 4.6 Tourist Perceptions of Activities in Pondok Mepantigan

\begin{tabular}{|c|c|c|c|c|}
\hline $\begin{array}{l}\mathrm{N} \\
\mathrm{o}\end{array}$ & Statement & Perception & Amount & $\begin{array}{c}\text { Percentag } \\
\mathrm{e}\end{array}$ \\
\hline \multirow[t]{5}{*}{1.} & \multirow{5}{*}{$\begin{array}{l}\text { I am pleased with the } \\
\text { activities of mask painting }\end{array}$} & Strongly Agree (5) & 25 People & $62,5 \%$ \\
\hline & & Agree (4) & 12 People & $30 \%$ \\
\hline & & $\begin{array}{l}\text { Neither Agree nor } \\
\text { Disagree (3) }\end{array}$ & 3 People & $7,5 \%$ \\
\hline & & Disagree & - & - \\
\hline & & Strongly Disagree & - & - \\
\hline \multicolumn{3}{|c|}{ Total } & 40 People & $100 \%$ \\
\hline \multirow[t]{5}{*}{2.} & \multirow{5}{*}{$\begin{array}{l}\text { I am pleased by doing the } \\
\text { exercise of mepantigan } \\
\text { before playing at mud }\end{array}$} & Strongly Agree (5) & 27 People & $67,5 \%$ \\
\hline & & Agree (4) & 12 People & $30 \%$ \\
\hline & & $\begin{array}{l}\text { Neither Agree nor } \\
\text { Disagree (3) }\end{array}$ & 1 People & $2,5 \%$ \\
\hline & & Disagree & - & - \\
\hline & & Strongly Disagree & - & - \\
\hline \multicolumn{3}{|c|}{ Total } & 40 People & $100 \%$ \\
\hline \multirow[t]{5}{*}{3.} & \multirow{5}{*}{$\begin{array}{l}\text { I am pleased by doing } \\
\text { mepantigan games at mud }\end{array}$} & Strongly Agree (5) & 30 People & $75 \%$ \\
\hline & & Agree (4) & 9 People & $22,5 \%$ \\
\hline & & $\begin{array}{l}\text { Neither Agree nor } \\
\text { Disagree (3) }\end{array}$ & 1 People & $2,5 \%$ \\
\hline & & Disagree & - & - \\
\hline & & Strongly Disagree & - & - \\
\hline \multicolumn{3}{|c|}{ Total } & 40 People & $100 \%$ \\
\hline \multirow[t]{5}{*}{4.} & \multirow{5}{*}{$\begin{array}{l}\text { I am interested in the } \\
\text { unique words as long as } \\
\text { playing mepantigan and } \\
\text { make me an enthusiast }\end{array}$} & Strongly Agree (5) & 28 People & $70 \%$ \\
\hline & & Agree (4) & 11 People & $27,5 \%$ \\
\hline & & $\begin{array}{l}\text { Neither Agree nor } \\
\text { Disagree (3) }\end{array}$ & 1 People & $2,5 \%$ \\
\hline & & Disagree & - & - \\
\hline & & Strongly Disagree & - & - \\
\hline
\end{tabular}




\begin{tabular}{|c|l|l|c|c|}
\hline \multicolumn{2}{|c|}{ Total } & 40 People & $\mathbf{1 0 0} \%$ \\
\hline 5. & $\begin{array}{l}\text { I am pleased with washing } \\
\text { clothes activity at the river }\end{array}$ & Strongly Agree (5) & 22 People & $55 \%$ \\
\cline { 3 - 5 } & Agree (4) & 15 People & $37,5 \%$ \\
\cline { 3 - 5 } & $\begin{array}{l}\text { Neither Agree nor } \\
\text { Disagree (3) }\end{array}$ & 2 People & $5 \%$ \\
\cline { 3 - 5 } & Disagree & 1 People & $2,5 \%$ \\
\cline { 3 - 5 } & Strongly Disagree & - & - \\
\hline \multirow{2}{*}{ Total } & $\begin{array}{l}\text { I am pleased and feel } \\
\text { challenging with fire ball } \\
\text { games }\end{array}$ & Strongly Agree (5) & 25 People & $62,5 \%$ \\
\cline { 3 - 5 } & Agree (4) & 12 People & $30 \%$ \\
\cline { 3 - 5 } & $\begin{array}{l}\text { Neither Agree nor } \\
\text { Disagree (3) }\end{array}$ & 3 People & $7,5 \%$ \\
\cline { 3 - 5 } & Disagree & - & - \\
\cline { 3 - 5 } & Strongly Disagree & - & - \\
\hline \multirow{2}{*}{ Total } & & $\mathbf{4 0}$ People & $\mathbf{1 0 0} \%$ \\
\hline
\end{tabular}

Source: Research Results, 2017

Based on table 4.7, respondents who feel the water supply has both stated strongly agree as many as 9 respondents with a percentage of 22.5 per cent, 22 respondents agree with a percentage of 55 per cent and 9 respondents are hesitant with a percentage of 22.5 per cent due to the lack use of water at Pondok Mepantigan. Respondents who felt the availability of electricity had sufficiently stated strongly agree as many as 10 respondents with a percentage of 25 per cent, 22 respondents agree with a percentage of 55 per cent and hesitant 8 respondents with a percentage of 20 per cent because respondents do not use electricity while in Pondok Mepantigan. The existence of directions facilitates the respondents who state strongly agree as many as 7 respondents with a percentage of 17.5 per cent, 22 respondents agree with percentage of 55 per cent, 10 respondents are hesitant with the percentage of 25 per cent and 1 respondent disagree with the percentage of 2.5 per cent. Respondents who felt the provision of the trashbin had adequately stated strongly agree as many as 12 respondents with a percentage of 30 per cent, 21 respondents agree with a percentage of 52.5 per cent and 7 respondents are hesitant with a percentage of 17.5 per cent. Respondents who felt the provision of adequate parking space stated strongly agree as many as 5 respondents with a percentage of 12.5 per cent, 22 respondents agree with a percentage of 55 per cent, 12 respondents hesitate with percentage of 30 per cent and 1 respondent disagrees with percentage of 2.5 per cent due to the inadequate parking lot in Pondok Mepantigan. Respondents who felt the provision of P3K (first aid kit) or the hospital or puskesmas had both stated strongly agree as many as 6 respondents with a percentage of 15 per cent, 22 respondents agree with a percentage of 55 per cent, 11 respondents hesitate with a percentage of 27.5 percent and disagree 1 respondent with a percentage of 2.5 percent. Respondents who feel ease of telecommunication or signal have stated strongly agree as many as 7 respondents with percentage of 17.5 percent, agree 23 respondents with percentage of 57.5 percent, hesitate 8 respondents with percentage of 20 percent and disagree 1 respondent with percentage of 2.5 percent and strongly disagree 1 respondent with a percentage of 2.5 percent because there are some signals that can not be used while in the Pondok Mepantigan. The existence of a bank or money changer around Pondok Mepantigan 
facilitate the respondents who state strongly agree as many as 5 respondents with a percentage of 12.5 per cent, agree 18 respondents with a percentage of 45 per cent, hesitate 16 respondents with percentage of 40 per cent and disagree 1 respondent with a percentage of 2.5 percent.

Table 4.7 Tourist Perceptions of Ancillary Services in Pondok Mepantigan

\begin{tabular}{|c|c|c|c|c|}
\hline $\begin{array}{l}\mathrm{N} \\
\mathrm{O}\end{array}$ & Statement & Perception & Amount & Percentage \\
\hline \multirow[t]{5}{*}{1.} & \multirow{5}{*}{$\begin{array}{l}\text { I feel the availability of } \\
\text { water was good }\end{array}$} & Strongly Agree (5) & 9 People & $22,5 \%$ \\
\hline & & Agree (4) & 22 People & $55 \%$ \\
\hline & & $\begin{array}{l}\text { Neither Agree nor } \\
\text { Disagree (3) }\end{array}$ & 9 People & $22,5 \%$ \\
\hline & & Disagree & - & - \\
\hline & & Strongly Disagree & - & - \\
\hline \multicolumn{3}{|c|}{ Total } & 40 People & $100 \%$ \\
\hline \multirow[t]{5}{*}{2.} & \multirow{5}{*}{$\begin{array}{l}\text { I feel the availability of } \\
\text { electricity was adequate }\end{array}$} & Strongly Agree (5) & 10 People & $25 \%$ \\
\hline & & Agree (4) & 22 People & $55 \%$ \\
\hline & & $\begin{array}{l}\text { Neither Agree nor } \\
\text { Disagree (3) }\end{array}$ & 8 People & $20 \%$ \\
\hline & & Disagree & - & - \\
\hline & & Strongly Disagree & - & - \\
\hline \multicolumn{3}{|c|}{ Total } & 40 People & $100 \%$ \\
\hline \multirow[t]{5}{*}{3.} & \multirow{5}{*}{$\begin{array}{l}\text { The availability of } \\
\text { signpost make me easy }\end{array}$} & Strongly Agree (5) & 7 People & $17,5 \%$ \\
\hline & & Agree (4) & 22 People & $55 \%$ \\
\hline & & $\begin{array}{l}\text { Neither Agree nor } \\
\text { Disagree (3) }\end{array}$ & 10 People & $25 \%$ \\
\hline & & Disagree & 1 People & $2,5 \%$ \\
\hline & & Strongly Disagree & - & - \\
\hline \multicolumn{3}{|c|}{ Total } & 40 People & $100 \%$ \\
\hline \multirow[t]{5}{*}{4.} & \multirow{5}{*}{$\begin{array}{l}\text { I feel the provided of } \\
\text { trash can was adequate }\end{array}$} & Strongly Agree (5) & 12 People & $30 \%$ \\
\hline & & Agree (4) & 21 People & $52,5 \%$ \\
\hline & & $\begin{array}{l}\text { Neither Agree nor } \\
\text { Disagree (3) }\end{array}$ & 7 People & $17,5 \%$ \\
\hline & & Disagree & - & - \\
\hline & & Strongly Disagree & - & - \\
\hline \multicolumn{3}{|c|}{ Total } & 40 People & $100 \%$ \\
\hline \multirow[t]{5}{*}{5.} & \multirow{5}{*}{$\begin{array}{l}\text { I feel the provided of } \\
\text { parking area was } \\
\text { adequate }\end{array}$} & Strongly Agree (5) & 5 People & $12,5 \%$ \\
\hline & & Agree (4) & 22 People & $55 \%$ \\
\hline & & $\begin{array}{l}\text { Neither Agree nor } \\
\text { Disagree (3) }\end{array}$ & 12 People & $30 \%$ \\
\hline & & Disagree & 1 People & $2,5 \%$ \\
\hline & & Strongly Disagree & - & - \\
\hline \multicolumn{3}{|c|}{ Total } & 40 People & $100 \%$ \\
\hline \multirow[t]{2}{*}{6.} & & Strongly Agree (5) & 6 People & $15 \%$ \\
\hline & & Agree (4) & 22 People & $55 \%$ \\
\hline
\end{tabular}




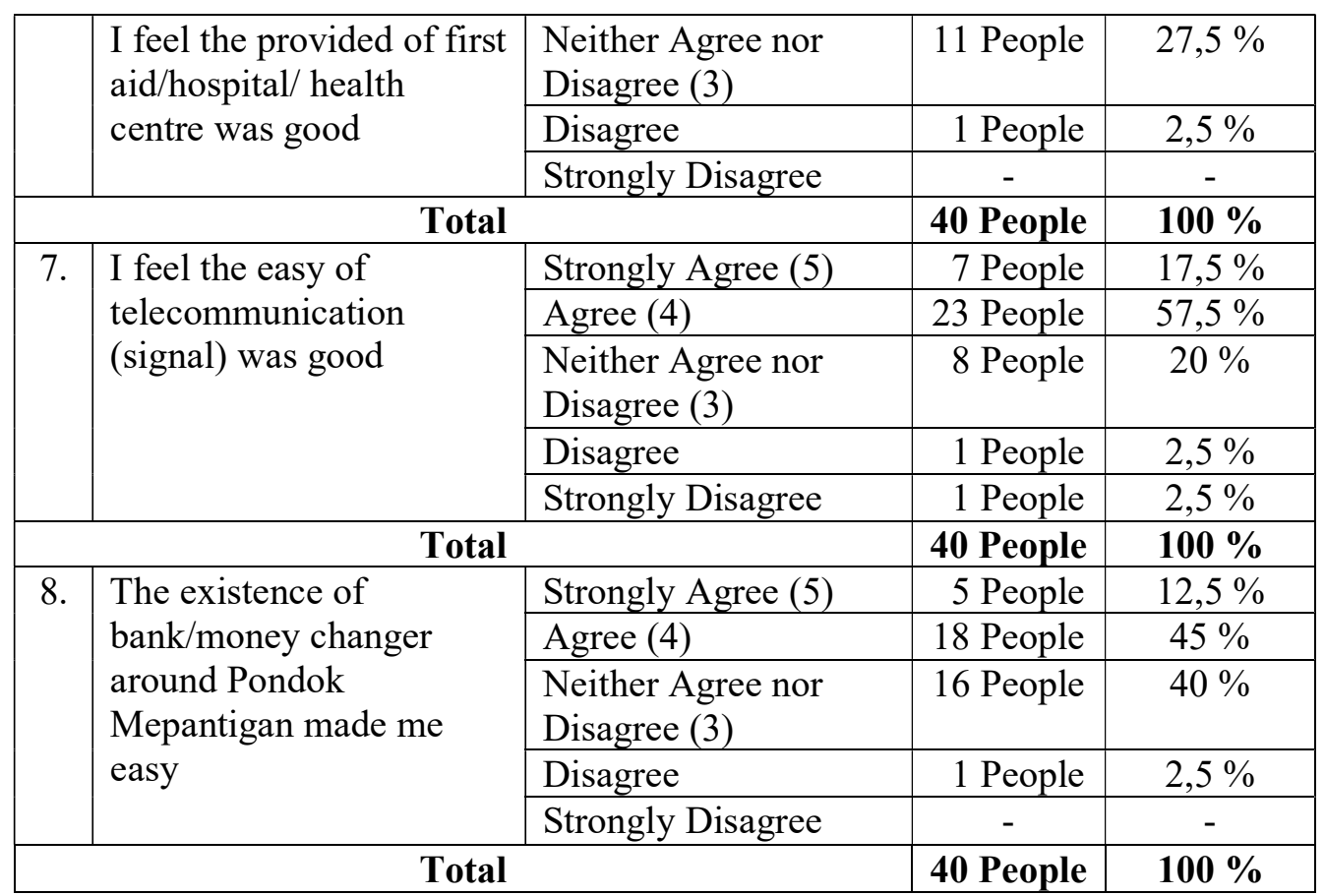

Source: Research Results, 2017

According to the perception towards Environmentally Sustainable in Pondok Mepantigan, the respondents who feel that Pondok Mepantigan has maintained the natural environment conserves strongly agree as many as 31 respondents with percentage of 77.5 per cent, agree 7 respondents with a percentage of 17.5 per cent and hesitant 2 respondents with a percentage of 5 per cent. Respondents who feel hospitality and ease of communication in Pondok Mepantigan have very well stated strongly agree as many as 29 respondents with a percentage of 72.5 per cent, agree 9 respondents with a percentage of 22.5 per cent and hesitant 2 respondents with a percentage of 5 per cent. Respondents who feel that Pondok Mepantigan will create a balanced economic life states strongly agree as many as 26 respondents with a percentage of 65 per cent, 9 respondents agree with a percentage of 22.5 per cent and hesitant 5 respondents with a percentage of 12.5 per cent. Respondents who feel that the Pondok Mepantigan has maintained the culture well stated strongly agree as many as 30 respondents with the percentage of 75 per cent, agree 8 respondents with percentage of 20 per cent and hesitant 2 respondents with percentage of 5 per cent. Overall it can be concluded that Pondok Mepantigan conforms to environmentally sustainable parameters in the development of alternative tourism.

Refers to the Social \& Culturally Acceptable components, the respondents who feel Pondok Mepantigan teach morale value in every game very well stated strongly agree as many as 26 respondents with percentage of 65 per cent, agree 13 respondents with percentage of 32.5 percent and hesitant 1 respondent with the percentage of 2.5 per cent. Respondents who feel that Mepantigan Pondok teaches about the local culture have both stated strongly agree as many as 28 respondents with the percentage of 70 per cent, 11 respondents agree with a percentage of 27.5 per cent and 1 respondent is hesitant with a percentage of 2.5 per cent. Respondents who feel Pondok Mepantigan obedient to the value of customs have either stated 
strongly agree as many as 24 respondents with a percentage of 60 per cent and 16 respondents agree with a percentage of 40 percent. Respondents who are happy with Pondok Mepantigan adopt the values of local wisdom stated strongly agree as many as 30 respondents with percentage of 75 percent and 10 respondents agree with a percentage of 25 percent. Overall it can be concluded that Pondok Mepantigan accordance with social and culturally acceptable parameters in the development of alternative tourism.

Table 4.8 Tourist Perception of Economically Viable in Pondok Mepantigan

\begin{tabular}{|c|c|c|c|c|}
\hline $\begin{array}{l}\mathrm{N} \\
\mathrm{O}\end{array}$ & Statement & Perception & Amount & Percentage \\
\hline \multirow[t]{5}{*}{1.} & \multirow{5}{*}{$\begin{array}{l}\text { I believe that Pondok } \\
\text { Mepantigan give } \\
\text { contribution to the } \\
\text { country both directly or } \\
\text { indirectly }\end{array}$} & Strongly Agree (5) & 25 People & $62,5 \%$ \\
\hline & & Agree (4) & 10 People & $25 \%$ \\
\hline & & $\begin{array}{l}\text { Neither Agree nor } \\
\text { Disagree (3) }\end{array}$ & 5 People & $12,5 \%$ \\
\hline & & Disagree & - & - \\
\hline & & Strongly Disagree & - & - \\
\hline \multicolumn{3}{|c|}{ Total } & 40 People & $100 \%$ \\
\hline \multirow[t]{5}{*}{2.} & \multirow{5}{*}{$\begin{array}{l}\text { I believe that Pondok } \\
\text { Mepantigan give } \\
\text { contribution to the } \\
\text { regional both directly or } \\
\text { indirectly }\end{array}$} & Strongly Agree (5) & 31 People & $77,5 \%$ \\
\hline & & Agree (4) & 6 People & $15 \%$ \\
\hline & & $\begin{array}{l}\text { Neither Agree nor } \\
\text { Disagree (3) }\end{array}$ & 3 People & $7,5 \%$ \\
\hline & & Disagree & - & - \\
\hline & & Strongly Disagree & - & - \\
\hline \multicolumn{3}{|c|}{ Total } & 40 People & $100 \%$ \\
\hline \multirow[t]{5}{*}{3.} & \multirow{5}{*}{$\begin{array}{l}\text { I believe that Pondok } \\
\text { Mepantigan give a } \\
\text { contribution to the } \\
\text { society both directly or } \\
\text { indirectly }\end{array}$} & Strongly Agree (5) & 28 People & $70 \%$ \\
\hline & & Agree (4) & 9 People & $22,5 \%$ \\
\hline & & $\begin{array}{l}\text { Neither Agree nor } \\
\text { Disagree (3) }\end{array}$ & 2 People & $5 \%$ \\
\hline & & Disagree & 1 People & $2,5 \%$ \\
\hline & & Strongly Disagree & - & - \\
\hline \multicolumn{3}{|c|}{ Total } & 40 People & $100 \%$ \\
\hline
\end{tabular}

Source: Research Results, 2017 
Figure 1 - 2 Basic Movement of "Mepantigan" at Pondok Mepantigan, Gianyar - Bali
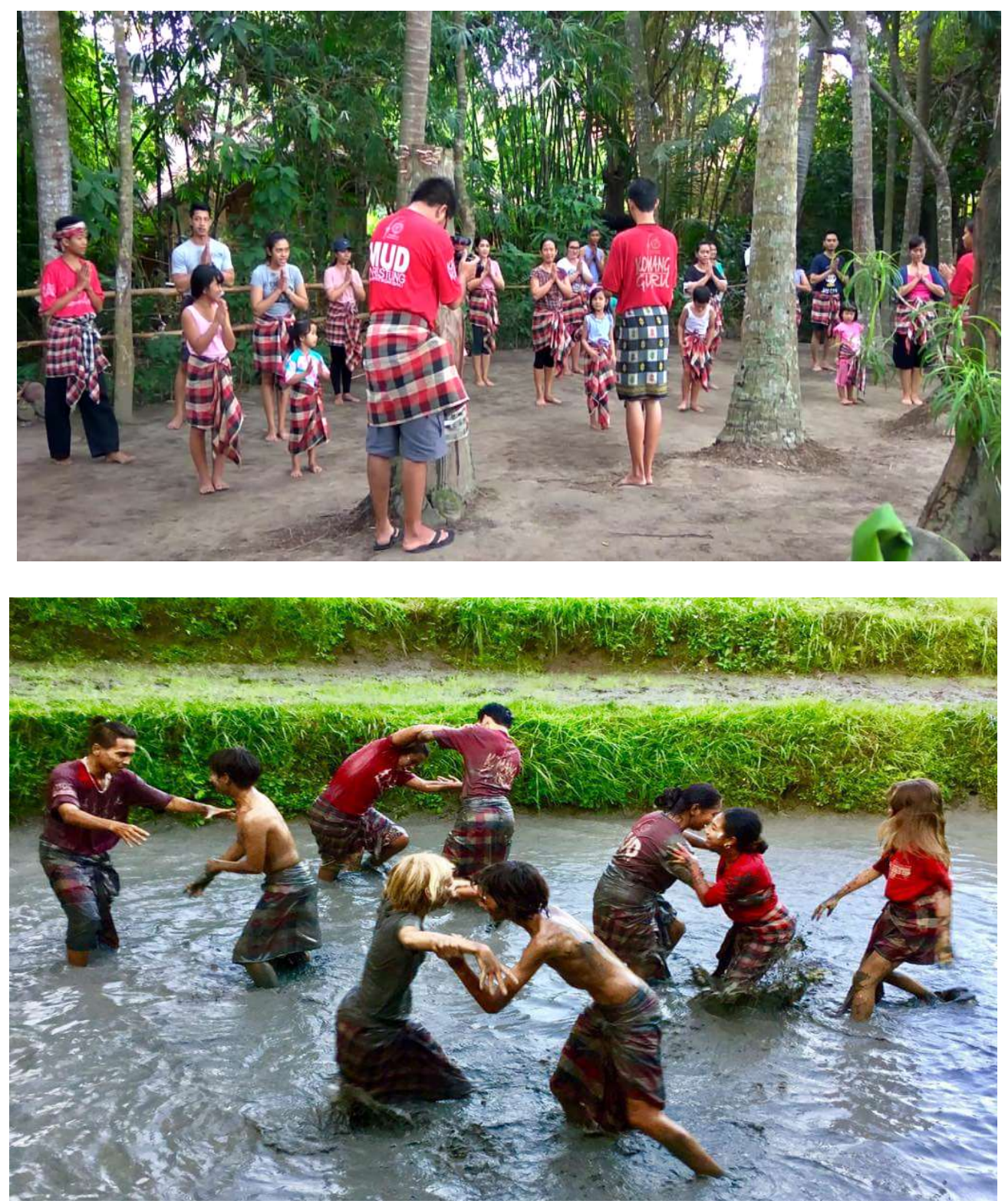

Source: Hani, Trivena (2017)

Based on Table 4.8, respondents believe that Pondok Mepantigan contributes to the state either directly or indirectly stated strongly agree as many as 25 respondents with a percentage of 62.5 per cent, 10 respondents agree with a percentage of 25 per cent and 5 respondents are hesitant with a percentage of 12.5 per cent. Respondents believe that Pondok Mepantigan contributed to the government either directly or indirectly stated strongly agree as many as 31 respondents with the percentage of 77.5 per cent, 6 respondents agree with a percentage of 15 per cent and 3 respondents are hesitant with a percentage of 7.5 per cent. Respondents believe that Pondok Mepantigan contributed to the 
community either directly or indirectly stated strongly agree as many as 28 respondents with a percentage of 70 per cent, 9 respondents agree with a percentage of 22.5 per cent, 2 respondents are hesitant with a percentage of 5 per cent and 1 of respondent disagree with a percentage of 2.5 per cent. Overall it can be concluded that Pondok Mepantigan conforms to economically viable parameters in the development of alternative tourism.

Table 4.9 Tourist Perception of Technologically Appropriate in Pondok Mepantigan

\begin{tabular}{|c|c|c|c|c|}
\hline $\begin{array}{l}\mathrm{N} \\
\mathrm{O}\end{array}$ & Statement & Persepsi / Penilaian & Amount & Percentage \\
\hline \multirow[t]{5}{*}{1.} & \multirow{5}{*}{$\begin{array}{l}\text { I am pleased that } \\
\text { Pondok Mepantigan } \\
\text { used eco-friendly } \\
\text { technology }\end{array}$} & Strongly Agree (5) & 31 People & $77,5 \%$ \\
\hline & & Agree (4) & 9 People & $22,5 \%$ \\
\hline & & $\begin{array}{l}\text { Neither Agree nor } \\
\text { Disagree (3) }\end{array}$ & - & - \\
\hline & & Disagree & - & - \\
\hline & & Strongly Disagree & - & - \\
\hline \multicolumn{3}{|c|}{ Total } & 40 People & $100 \%$ \\
\hline \multirow[t]{5}{*}{2.} & \multirow{5}{*}{$\begin{array}{l}\text { I am pleased with the } \\
\text { welcoming and } \\
\text { participation of } \\
\text { society/staff in Pondok } \\
\text { Mepantigan }\end{array}$} & Strongly Agree (5) & 30 People & $75 \%$ \\
\hline & & Agree (4) & 10 People & $25 \%$ \\
\hline & & $\begin{array}{l}\text { Neither Agree nor } \\
\text { Disagree (3) }\end{array}$ & - & - \\
\hline & & Disagree & - & - \\
\hline & & Strongly Disagree & - & - \\
\hline \multicolumn{3}{|c|}{ Total } & 40 People & $100 \%$ \\
\hline
\end{tabular}

Source: Research Results, 2017

Based on table 4.9, respondents who feel happy that Pondok Mepantigan using environmentally friendly technology states strongly agree as many as 31 respondents with a percentage of 77.5 per cent and agree 9 respondents with a percentage of 22.5 per cent. Respondents are happy with the community or staff of Pondok Mepantigan who are open and participate in Pondok Mepantigan stated strongly agree as many as 30 respondents with percentage of 75 per cent and 10 respondents agree with a percentage of 25 per cent. Overall it can be concluded that Pondok Mepantigan conforms to technologically appropriate parameters in the development of alternative tourism.

\section{CONCLUSION}

Based on this research, it can be concluded that Pondok Mepantigan has a natural tourist attraction, culture and artificial. In general, the tourists' perception, they like of attraction, accommodation (amenities), packages (available packages), and activities. While the ancillary services indicator needs further development in terms of availability of clean water and telecommunication ease. In accessibility, it needs further improvement considering accessibility is beyond the authority and is the responsibility of Pondok Mepantigan. The perception of tourists towards mepantigan as alternative tourism is compatible with alternative tourism 
parameters. Especially on being environmentally sustainable, acceptable to socially and culturally acceptable societies and viable, economically viable, utilizing appropriate technology to be applied in the area of the environment (technologically appropriate). However, there needs to be an increase in the technologically appropriate parameters to empower the local community as much as possible.

Referring to the results of research for feedback that needs to be considered by the stakeholders are as follows:

a) Stakeholder can support promoting Pondok Mepantigan through social media, print media and electronic media and should develop other alternative tourism attractions so that tourists have more reference to alternative tourism attraction.

b) Pondok Mepantigan Manager provides English training to the community, involves the community in planning, involves the community in organizational structure and decision making in Pondok Mepantigan.

c) With the attraction of Pondok Mepantigan, it can be used as an example for the community to lift, preserve, and create a new tourist attraction with the main elements of Balinese culture and which can be packaged like the one in Pondok Mepantigan.

\section{REFERENCES}

[1] Arcana, Komang Trisna Pratiwi, 2014. "The Implementation of Sustainable Event Management in BTDC Nusa Dua Bali”. Thesis.France L'universite d'Anjers.

[2] Badan Pusat Statistik Provinsi Bali. 2011. (https://bali.bps.go.id/linkTableDinamis/view/id/64) diakses pada tanggal 6 Juni 2017.

[3] Buhalis. 2000. Menunjukan Destinasi Wisata Terdiri dari Beberapa Komponen, Jakarta: PT Gramedia.

[4] Migang, Rio Setiawan, dkk. 2010. Pariwisata Kalimantan: Pemikiran dan Perjalanan ke Jantung Borneo. Jakarta: Arsimedik Publisher.

[5] Pantiyasa, 2013. Metodelogi Penelitian. Denpasar: Sekolah Tinggi Pariwisata Bali Internasional.

[6] Rangkuti, F. 2002. Riset Pemasaran. Jakarta: Gramedia Pustaka Utama.

[7] Sunaryo, Bambang. 2013. Kebijakan Pembangunan Destinasi Pariwisata Konsep dan Aplikasinya di Indonesia.Yogyakarta: Gava Media.

[8] Sunaryo. 2004. Psikologi Untuk Keperawatan. Jakarta:EGC.

[9] Suwantoro, G. 2004. Dasar-dasar Pariwisata. Yogyakarta: CV Andi Offset.

[10] Tim Penyusun Biro Hukum dan Komunikasi Publik. 2015. Peringatan Hari Pariwisata Dunia Pariwisata Pendorong Pertumbuhan Ekonomi Inklusif dan Berkelanjutan. Bulletin Destinasi dan Industri Pariwisata, September. 1516.

[11] Valene, L. S. 2001. Aternative Tourism. London : Publishing. 